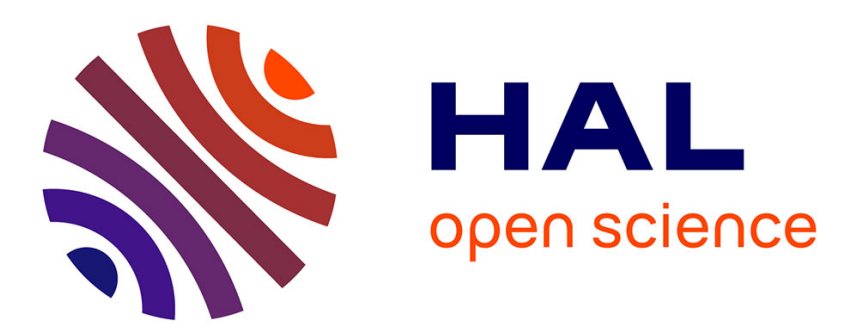

\title{
Development and validation of a new TRNSYS type for the simulation of external building walls containing PCM
}

\author{
F. Kuznik, J. Virgone, K. Johannes
}

\section{- To cite this version:}

F. Kuznik, J. Virgone, K. Johannes. Development and validation of a new TRNSYS type for the simulation of external building walls containing PCM. Energy and Buildings, 2010, 42 (7), pp.10041009. 10.1016/j.enbuild.2010.01.012 . hal-00541886

\section{HAL Id: hal-00541886 \\ https://hal.science/hal-00541886}

Submitted on 9 Jun 2014

HAL is a multi-disciplinary open access archive for the deposit and dissemination of scientific research documents, whether they are published or not. The documents may come from teaching and research institutions in France or abroad, or from public or private research centers.
L'archive ouverte pluridisciplinaire HAL, est destinée au dépôt et à la diffusion de documents scientifiques de niveau recherche, publiés ou non, émanant des établissements d'enseignement et de recherche français ou étrangers, des laboratoires publics ou privés. 


\title{
Development and Validation of a New TRNSYS Type for the Simulation of External Building Walls Containing PCM
}

\author{
Frédéric Kuznik ${ }^{\mathrm{a}, *}$, Joseph Virgone ${ }^{\mathrm{a}}$, Kevyn Johannes ${ }^{\mathrm{a}}$ \\ ${ }^{a}$ Université de Lyon, CNRS \\ INSA-Lyon, CETHIL, UMR5008, F-69621, Villeurbanne, France \\ Université Lyon 1, F-69622, France
}

\begin{abstract}
In building construction, the use of Phase Change Materials (PCM) allows the storage/release of energy from the solar radiation and/or internal loads. The application of such materials for lightweight construction (e.g., a wood house) makes it possible to improve thermal comfort and reduce energy consumption. However, in order to asses and optimize phase change materials included in building wall, numerical simulation is mandatory. For that purpose, a new TRNSYS Type, named Type 260, is developed to model the thermal behavior of an external wall with PCM. This model is presented in this paper and validated using experimental data from the literature.

Keywords: TRNSYS, phase change material, wall, thermal energy storage
\end{abstract}

\section{Introduction}

The use of phase change material (PCM) in building envelop is a relatively old concept for reducing energy consumption in passively designed

\footnotetext{
*Corresponding author. Tel.: +33-472-438-461; Fax: +33-472-438-522

Email address: frederic.kuznik@insa-lyon.fr (Frédéric Kuznik)
} 
buildings [1]. However, the use of PCM has regained interest only in the last decade; this tendency being confirmed by the literature: [2], [3], [4],...

However, many materials with various mixtures exist, as well as many configurations of PCM integration in the building envelop [5]. An optimization of PCM is then necessary, considering the building struture, the integration of PCM in the envelop and the geographical location. This work can only be done using numerical simulations. Nowadays, building energy simulations tools are numerous: BLAST, BSim, DeST, DOE, ECOTECT, EnerWin, Energy Express, Energy-10, EnergyPlus, eQUEST, ESP-r, IDA-ICE, IES, HAP, HEED, PowerDomus, SUNREL, Tas, TRACE, TRNSYS,...The TRNSYS tool is chosen for our work because of the possibility to connect the building with many other systems (HVAC, renewable energy) and its numerous validations [6].

Even if the physical equations for the PCM are well known, only few numerical models exist. Most of the numerical models concern the entire building modeling: [7], [8], [9], [10],... These models consider an unidirectional heat transfer in walls and an air energy balance equation to calculate the mean room air temperature. Then, these models cannot be adapted easily to any building configuration. Moreover, the PCM energy storage can be enhanced if coupled with HVAC systems (for example nighttime ventilation in summer for free-cooling), requiring a modular simulation tool structure like TRNSYS.

A first approach for the simulation of PCM walls using TRNSYS lies in the work of [11]. Their modeling does not aim a simulation of the real transfer process. The storage and release effects of PCM are simulated using 
the active layer tool in TRNSYS Type 56. The PCM procedure is a controller: the inputs are temperatures (wall and air) and the outputs data for the active layer in order to simulate the PCM effect from a global energetic point of view. This procedure allows to evaluate the influence of PCM in the whole energy balance of a room, but more experimental validations are needed.

In the work of Ahmad et al. [12], a model of the Helsinki University of Technology has been adapted to be used as a PCM wall in TRNSYS. This model consists in 729 finite volume nodes, 9 nodes in each direction of the wall. The high node number slows down the simulations. Moreover, the specific heat capacity is fixed to a top hat temperature function.

In this paper, a TRNSYS type is presented and validated through experimental results. First, the modeling is presented and the assumptions are discussed. Data from literature are then used to validate the new TRNSYS Type developed in this study; they are presented in the part 3 . The last part of the paper deals with the comparisons between experimental data and numerical modeling.

\section{PCM Modeling}

\subsection{Implementation in TRNSYS environment}

TRNSYS is the acronym for TRaNsient SYStems simulation program and is developed at the University of Wisconsin [13]. The modular structure gives the program flexibility. The "Multi-zone Building " Type 56 is used to simulate the thermal behavior of a building. Then, the main problem lies in the way to connect the Type 56 with our model.

The Type 260, developed in this paper, is linked to Type 56 similarly to 
the "slab on grade" type in the TESS library [13]. The figure 1, figure 2 and figure 3 show the implementation principle of the type within TRNSYS.

The principles of the connection between Type 56 and the PCM Type 260 are (figure 1 and figure 2):

- The inside surface temperature, calculated by the Type 56, is used as an input for the PCM Type 260.

- The other inputs are the external conditions: solar heat flux (short wave radiation), ambient temperature and view factor (long wave radiation).

- The global conductance of the layers situated between the thermal zone and the PCM layer is a parameter of the Type 260.

- The layers situated between the PCM and the exterior, with a maximum of 4, are parameters of the Type 260 (thickness, physical properties, number of mesh nodes).

- The last parameters are the properties of the PCM:

- The effective or apparent heat capacity curve of the PCM $C_{P C M}=$ $f(T)$,

- Solid and liquid thermal conductivities.

\subsection{Numerical modeling}

\subsubsection{Assumptions}

The conduction heat transfer is supposed to be one-dimensional. The heat capacity, density and thermal conductivity of building materials are independent of temperature, except for the PCM layer. 
The phase change can be taken into account in the heat equation using either the effective heat capacity method or the enthalpy method. These two methods have been extensively studied in the literature, for example: [14], [15], [16] for the effective heat capacity method and [17], [18], [19] for the enthalpy formulation method. The two methods have the advantages of allowing to use one formulation of the heat equation for the entire domain and of avoiding to solve the melting front position. In our study, the effective heat capacity is used to model the heat transfer due to the phase change because it gives reliable results $([20])$.

\subsubsection{Basic equation}

In each layer $k$ composing the wall, the heat equation is:

$$
\rho_{k} \frac{\partial h_{k}}{\partial t}=-\frac{\partial}{\partial x}\left(\lambda_{k} \frac{\partial T}{\partial x}\right)
$$

$h_{k}$ is the enthalpy of the layer $k$. For non phase change building materials, partial derivative of enthalpy is given by:

$$
\frac{\partial h_{k}}{\partial t}=C_{k} \frac{\partial T}{\partial t}
$$

with the heat capacity $C_{k}$ that remains constant. For the PCM material, the following formulation is used:

$$
\frac{\partial h_{P C M}}{\partial t}=\frac{\partial h_{P C M}}{\partial T} \frac{\partial T}{\partial t}=C_{P C M}(T) \frac{\partial T}{\partial t}
$$

with $C_{P C M}(T)$ the analytical expression of the effective heat capacity.

\subsubsection{Numerical methods}

The problem of heat transfer with PCM in wallboards cannot be solved algebraically because of the non-linearities. In order to solve numerically the 
problem, a finite-difference method is used: we have replaced the continuous informations contained in the exact solution of the differential equation with discrete temperature values $T_{n}^{i}$. The index $i$ concerns the space coordinate and $n$ the time coordinate.

The spatial discretization is a second-order finite-differences scheme. The time discretization is a first-order backward difference one. The discrete form of the heat equation 1 is given by the following equation 4 .

The finite difference scheme for the node $i$ inside the PCM is:

$$
\begin{aligned}
& \rho_{P C M} \frac{C_{i}^{n} \Delta x}{\Delta t}\left(T_{i}^{n+1}-T_{i}^{n}\right)=T_{i-1}^{n+1}\left(\frac{1}{\frac{\Delta x}{2 \lambda_{i-1}^{n}}+\frac{\Delta x}{2 \lambda_{i}^{n}}}\right) \\
& +T_{i}^{n+1}\left(\frac{1}{\frac{\Delta x}{2 \lambda_{i-1}^{n}}+\frac{\Delta x}{2 \lambda_{i}^{n}}}-\frac{1}{\frac{\Delta x}{2 \lambda_{i}^{n}+}+\frac{\Delta x}{2 \lambda_{i+1}^{n}}}\right)+T_{i+1}^{n+1}\left(\frac{1}{\frac{\Delta x}{2 \lambda_{i}^{n}}+\frac{\Delta x}{2 \lambda_{i+1}^{n}}}\right)
\end{aligned}
$$

The scheme is not fully implicit because the physical properties of the PCM are calculated at the previous time step.

The mean interior surface calculated by the multizone type and the external conditions are the boundary conditions of our modeling. Moreover, writing equation 4 for each node $i$, the evolution system of $T_{i}$ can be written in the matrix form as:

$$
\{T\}^{n+1}=\left[M\left(T^{n}\right)\right]\left(\{T\}^{n}+\{B\}^{n+1}\right)
$$

with $\{T\}$ the vector containing the node temperatures $T_{i},[M]$ a matrix with temperature-dependent heat capacity of PCM and $\{B\}$ a vector containing external solicitations.

In order to avoid numerical instabilities and discretization errors, the time step and spatial step are parameters of the Type 260 [21]. 


\section{Experiment}

The validation of the TRNSYS Type developed in this study uses experimental data from [22]. Then, the experiments are briefly described in this section and the reader can find more information in the cited reference.

\subsection{Phase change material tested}

The product tested has been achieved by the Dupont de Nemours Society and is called ENERGAIN ${ }^{\circledR}$. It is constituted of $60 \%$ of microencapsulated paraffin within a copolymer. The final form of the PCM material is a flexible sheet of $5 \mathrm{~mm}$ thickness which density is about $850 \mathrm{~kg} \cdot \mathrm{m}^{-3}$. The PCM heat capacity has been measured using a differential scanning calorimeter. The thermal analysis has been performed from $5^{\circ} \mathrm{C}$ to $35^{\circ} \mathrm{C}$. The PCM is not a pure or eutectic material then there is a difference between the freezing and heating curves (figure reffig1).

The heat conductivity has been measured using guarded hot-plate apparatus. The thermal conductivity is $0.22 W \cdot m^{-1} \cdot K^{-1}$ in solid phase $\left(T<5^{\circ} \mathrm{C}\right)$ and decreased to about $0.18 W \cdot m^{-1} \cdot K^{-1}$ in liquid phase $\left(T>25^{\circ} \mathrm{C}\right)$. We assumed that this conductivity decreases linearly during the phase change.

\subsection{Experimental test cell description}

The experimental test apparatus, which is named MICROBAT, is composed of two identical test cells. Each test cell is a cubical enclosure with an internal dimension of $0.50 m$ (figure 6).

Five of the box faces are identically built and the active face is a $2 \mathrm{~mm}$ layer of aluminium. All internal faces are painted in black and the external 
ones are in aluminium. All other faces are composed of $6 \mathrm{~cm}$ of insulated material, the difference between the two boxes being the addition of PCM in the PCM box according to figure 7 and figure 8. Only the 3 vertical faces contain phase change material wallboards in the PCM cell.

The two test cells MICROBAT have been placed in a climatic room where the temperature can be dynamically controlled, thus the two test cells are submitted to the same external conditions.

In each box the measurement probes are the same. The temperatures are monitored by the means of PT100 probes. The measurements concern:

○ the internal surface temperatures (6 probes in each box situated at the face center),

$\circ$ the internal air temperature,

$\circ$ the external air temperature,

o the external surface temperature of the faces.

\subsection{Conditions imposed inside the climatic room}

First, in order to achieve stationary initial conditions, the temperature are maintained at $15^{\circ} \mathrm{C}$ during 20 hours. This allows a temperature stabilization inside the two cells (stabilization verified using the monitored internal air temperatures of the two test cells). Then, the following procedure is executed:

* a linear external temperature increase from $15^{\circ} \mathrm{C}$ to $30^{\circ} \mathrm{C}$ during a time step of two hours,

* the external temperature is maintained at $30^{\circ} \mathrm{C}$ during 20 hours, 
* a linear external temperature decrease from $30^{\circ} \mathrm{C}$ to $15^{\circ} \mathrm{C}$ during a time step of two hours.

Sinusoidal variations of the temperatures have also been imposed with a 24 hours period. The amplitude of the temperature evolution is also $15^{\circ} \mathrm{C}$, between $15^{\circ} \mathrm{C}$ and $30^{\circ} \mathrm{C}$. This period of 24 hours has been repeated 3 times in order to get a stabilization of the temperature periodic evolution.

\subsection{Experimental results}

The figures 9 and figure 10 show the results obtained in the case of the temperature step with a time step of 2 hours and in the case of sinusoidal temperatures imposed in the climatic room.

The air temperature for the box without PCM is close to the exterior temperature with a little time lag due to the low thermal inertia of the box. The storage effect of PCM affects much the air temperature. Of course, the presence of PCM allows to delay the box air temperature increase or decrease (as long as the temperature varies within the phase change range).

The main difference between the heating and the cooling is the flat part of the curve around $19^{\circ} \mathrm{C}$ appearing only for the cooling step cases. This flat part of the curve lasts about $1 h$. The PCM composite is composed of microencapsulated paraffin included in a copolymer matrix. During the solidification process, the solid paraffin is evenly formed through the sphere, starting from the outer surface and moving inward. As the solidification proceeds, the melt volume decreases with a simultaneous decrease in the magnitude of natural convection within the melt and the process is therefore much longer [23]. 
The figure 10 shows the air temperature curves for the two cells in case of sinusoidal external air evolution. For the cell with PCM, the phase difference $\zeta=138$ min while this value is about 38 min without PCM.

\section{Comparison between experimental data and TRNSYS numeri- cal modeling}

\subsection{Main hypothesis}

The physical properties of the material used in the cell test are given in the table 1 . The heating heat capacity curve is used for the numerical modeling of the experiment. The Type 260 is connected to the TRNSYS Type 56 in order to model the MICROBAT test cell.

\subsection{Internal air temperature}

The figures 11 and 12 show the comparisons between the experimental data and the numerical modeling for the cell air temperature and for respectively the external temperature step and the external temperature sinusoidal evolution.

The numerical modeling are in good agreement with experimental data for the external temperature step increase/decrease. The maximum difference is $1.1^{\circ} \mathrm{C}$ and the mean difference is $0.2^{\circ} \mathrm{C}$. The maximum difference arise for the temperature decrease and concerns the flat part of the curve around $19^{\circ} \mathrm{C}$. This is due to the unability of the modeling to predict such physical phenomenon.

Concerning the sinusoidal external temperature evolution, the maximum difference is $0.8^{\circ} \mathrm{C}$ and the mean difference is $0.3^{\circ} \mathrm{C}$. The numerical modeling is in quite good agreement with the experiment. 


\subsection{Inside surfaces temperature}

Figure 13 and figure 14 present the indoor surface temperature of the cell vertical wallboards. The agreement between measured and computed values is good especially in the case of the temperature step solicitation with a maximum difference of $1.1^{\circ} \mathrm{C}$ and a mean difference of $0.2^{\circ} \mathrm{C}$. In the case of the sinusoidal solicitation, some differences appear according to the considered face which is not the case for the cell without PCM [22]. Indeed, in the measured values, a sensitive difference between the side wall and the back wall exists. The numerical results obtained with our modeling give a good representation of the measured values. However in this case, the presence of PCM involves aeraulic effects that our model is not able to reproduce. The model gives the same results for the three vertical wallboards of the cell with a maximum difference of $1.3^{\circ} \mathrm{C}$ and a mean difference of $0.6^{\circ} \mathrm{C}$ for the side walls.

\section{Conclusions}

The use of phase change material wallboards allows the enhancement of the thermal inertia of buildings. For its use with an optimal storage effect the material must be optimized using numerical modeling. The TRNSYS Type 260, developed for this purpose, is described in the paper and validated using experimental data from the literature.

Even if the numerical modeling is in good agreement with the data from experiments, some differences exist. First, the model cannot predict the phase change in the microcapsule. Second, the model cannot predict the aeraulic inside the cells. This last point can be enhanced if the correct 
convective heat transfer coefficient is known, especially during the phase change.

\section{References}

[1] D. Chahroudi, Thermoconcrete heat storage materials: applications and performance specifications., in: Proceeding of Sharing the Sun Solar Technology in the Seventies Conference, Winnipeg, USA, 1976.

[2] A. M. Khudhair, M. M. Farid, A review on energy conservation in building applications with thermal storage by latent heat using phase change materials, Energy Conversion and Management 45 (2) (2004) 263 - 275.

[3] V. V. Tyagi, D. Buddhi, Pcm thermal storage in buildings: A state of art, Renewable and Sustainable Energy Reviews 11 (6) (2007) 1146 1166.

[4] Y. Zhang, G. Zhou, K. Lin, Q. Zhang, H. Di, Application of latent heat thermal energy storage in buildings: State-of-the-art and outlook, Building and Environment 42 (6) (2007) 2197 - 2209.

[5] A. Hauer, H. Mehling, P. Schossig, M. Yamaha, L. Cabeza, V. Martin, F. Setterwall, Annex 17: Advanced thermal energy storage through phase change materials and chemical reactions - feasibility studies and demonstration projects, Tech. rep., Final Report of International Energy Agency (2005).

[6] D. B. Crawley, J. W. Hand, M. Kummert, B. T. Griffith, Contrasting the capabilities of building energy performance simulation programs, Build- 
ing and Environment 43 (4) (2008) 661 - 673, part Special: Building Performance Simulation.

[7] M. Koschenz, B. Lehmann, Development of a thermally activated ceiling panel with pcm for application in lightweight and retrofitted buildings, Energy and Buildings 36 (6) (2004) 567 - 578.

[8] K. Darkwa, P. O'Callaghan, Simulation of phase change drywalls in a passive solar building, Applied Thermal Engineering 26 (8-9) (2006) 853 -858 .

[9] G. Zhou, Y. Zhang, K. Lin, W. Xiao, Thermal analysis of a direct-gain room with shape-stabilized pcm plates, Renewable Energy 33 (6) (2008) $1228-1236$.

[10] C. Halford, R. Boehm, Modeling of phase change material peak load shifting, Energy and Buildings 39 (3) (2007) 298 - 305.

[11] M. Ibanez, A. Lazaro, B. Zalba, L. F. Cabeza, An approach to the simulation of pcms in building applications using trnsys, Applied Thermal Engineering 25 (11-12) (2005) 1796 - 1807.

[12] M. Ahmad, A. Bontemps, H. Salle, D. Quenard, Thermal testing and numerical simulation of a prototype cell using light wallboards coupling vacuum isolation panels and phase change material, Energy and Buildings 38 (6) (2006) $673-681$.

[13] S. A. K. et al., TRNSYS 16 - A TRansient SYstem Simulation program, User Manual, Solar Energy Laboratory, Madison: University of Wisconsin-Madison (2004). 
[14] L. E. Goodrich, Efficient numerical technique for one-dimensional thermal problems with phase change, International Journal of Heat and Mass Transfer 21 (5) (1978) 615 - 621.

[15] G. Comini, S. D. Guidice, R. W. Lewis, O. C. Zienkiewicz, Finite element solution of non-linear heat conduction problems with special reference to phase change, International Journal for Numerical Methods in Engineering 8 (3) (1974) 613-624.

[16] Y. Minwu, A. Chait, An alternative formulation of the apparent heat capacity method for phase-change problems, J Numerical Heat Transfer, Part B: Fundamentals: An International Journal of Computation and Methodology 24 (3) (1993) 279-300.

[17] S. Kakac, Y. Yener, Heat Conduction, 4th Edition, Taylor \& Francis, 2008.

[18] V. Voller, M. Cross, Accurate solutions of moving boundary problems using the enthalpy method, International Journal of Heat and Mass Transfer 24 (3) (1981) $545-556$.

[19] A. Date, A strong enthalpy formulation for the stefan problem, International Journal of Heat and Mass Transfer 34 (9) (1991) 2231 - 2235.

[20] F. Kuznik, J. Virgone, J. Noel, Optimization of a phase change material wallboard for building use, Applied Thermal Engineering 28 (11-12) (2008) $1291-1298$. 
[21] F. Kuznik, J. Virgone, J.-J. Roux, Energetic efficiency of room wall containing pcm wallboard: A full-scale experimental investigation, Energy and Buildings 40 (2) (2008) $148-156$.

[22] F. Kuznik, J. Virgone, Experimental investigation of wallboard containing phase change material: Data for validation of numerical modeling, Energy and Buildings 41 (5) (2009) $561-570$.

[23] H. Ettouney, H. El-Dessouky, A. Al-Ali, Heat transfer during phase change of paraffin wax stored in spherical shells, Journal of Solar Energy Engineering 127 (3) (2005) 357-365. 


\section{List of Tables}

1 Thermophysical properties of the materials. . . . . . . . . 18 


\begin{tabular}{|llll|}
\hline LIST OF SYMBOLS & & \\
$C$ & specific heat $[\mathrm{J} / \mathrm{kg} K]$ & $\rho$ & mass density $\left[\mathrm{kg} / \mathrm{m}^{3}\right]$ \\
$h$ & enthalpy $[\mathrm{J} / \mathrm{kg}]$ & $\lambda$ & thermal conductivity $[\mathrm{W} / \mathrm{mK}]$ \\
$T$ & temperature $[\mathrm{K}]$ & \multicolumn{3}{l|}{} \\
$t$ & time $[\mathrm{s}]$ & \multicolumn{2}{l|}{ Subscripts } \\
$x$ & coordinate $[\mathrm{m}]$ & $i$ & node position \\
& & $k$ & layer \\
Greek Letters & & $P C M$ & phase change material \\
$\Delta t$ & time step $[\mathrm{s}]$ & \multicolumn{2}{c}{} \\
$\Delta x$ & mesh size $[\mathrm{m}]$ & \multicolumn{2}{c}{ Superscript } \\
& & $n$ & time coordinate \\
\hline
\end{tabular}




\begin{tabular}{lccc}
\cline { 2 - 4 } & $\begin{array}{c}\text { density } \\
{\left[\mathrm{kg} / \mathrm{m}^{3}\right]}\end{array}$ & $\begin{array}{c}\text { specific heat } \\
{[\mathrm{J} / \mathrm{kg} \mathrm{K}]}\end{array}$ & $\begin{array}{c}\text { thermal conductivity } \\
{[\mathrm{W} / \mathrm{mK}]}\end{array}$ \\
\hline aluminium & 2700 & 8800 & 230.00 \\
insulating material & 35 & 1210 & 0.04 \\
cardboard & 730 & 1110 & 0.27 \\
\hline
\end{tabular}

Table 1: Thermophysical properties of the materials. 


\section{List of Figures}

1 Practical implementation of the PCM type. . . . . . . . . . 20

2 Schematic of the Type 260. . . . . . . . . . . . . . 21

3 TRNSYS flow diagram with PCM type. . . . . . . . . . . . 22

4 RC model of the wallboard. . . . . . . . . . . . . . . . 23

5 Measurement of the PCM heat capacity. . . . . . . . . . . 24

6 Schematic view of the experimental cell MICROBAT. . . . . . 25

7 Wall composition of the box with PCM. . . . . . . . . . . 26

8 Wall composition of the box without PCM. . . . . . . . . . 27

9 Experimental cells air temperatures with and without PCM:

two hours increase/decrease. . . . . . . . . . . . . . . 28

10 Experimental cells air temperatures with and without PCM:

Sinusoidal temperature. . . . . . . . . . . . . . . . . . 29

11 Comparison of simulated and measured air temperature of the test cell with PCM: two hours increase/decrease external temperature. . . . . . . . . . . . . . . . 30

12 Comparison of simulated and measured air temperature of the test cell with PCM: sinusoidal external temperature. . . . . . 31

13 Comparison of simulated and measured inside vertical surface temperatures of the test cell with PCM: two hours increase/decrease external temperature. . . . . . . . . . . 32

14 Comparison of simulated and measured inside vertical surface temperatures of the test cell with PCM: sinusoidal external temperature evolution. . . . . . . . . . . . . . 33 


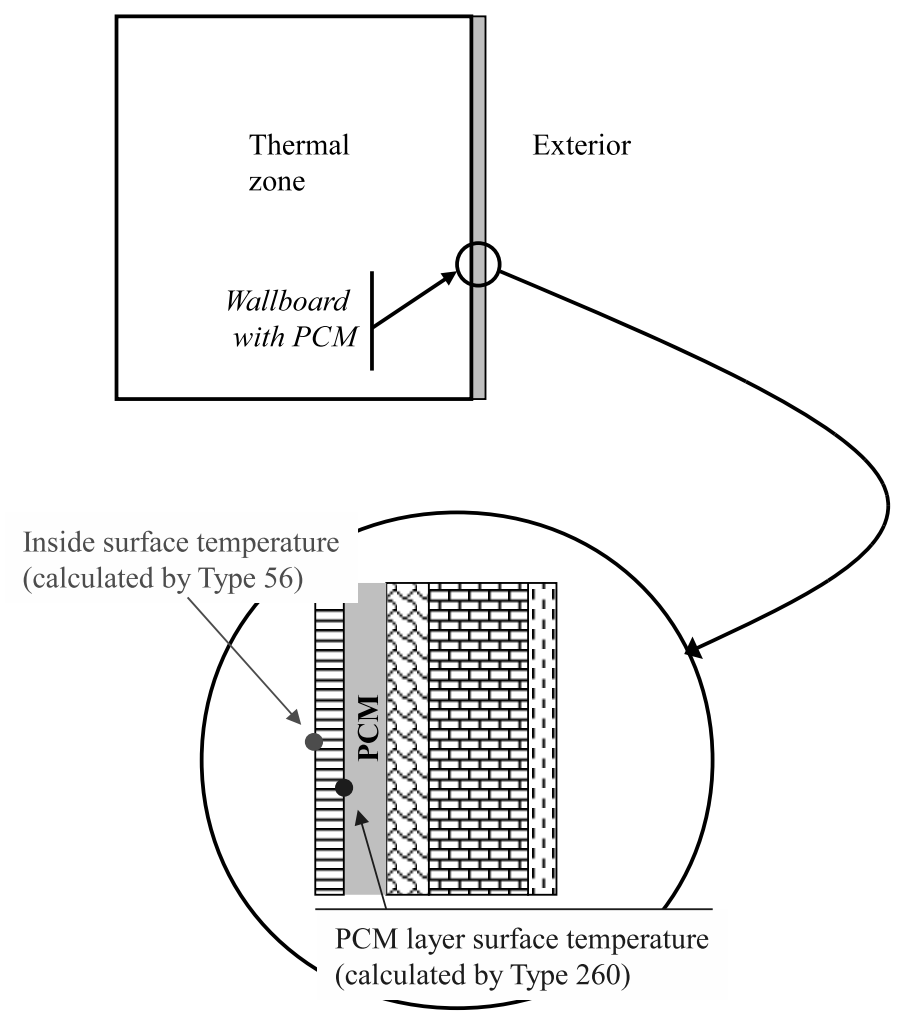

Figure 1: Practical implementation of the PCM type. 


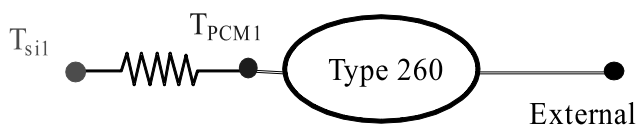

Figure 2: Schematic of the Type 260. 


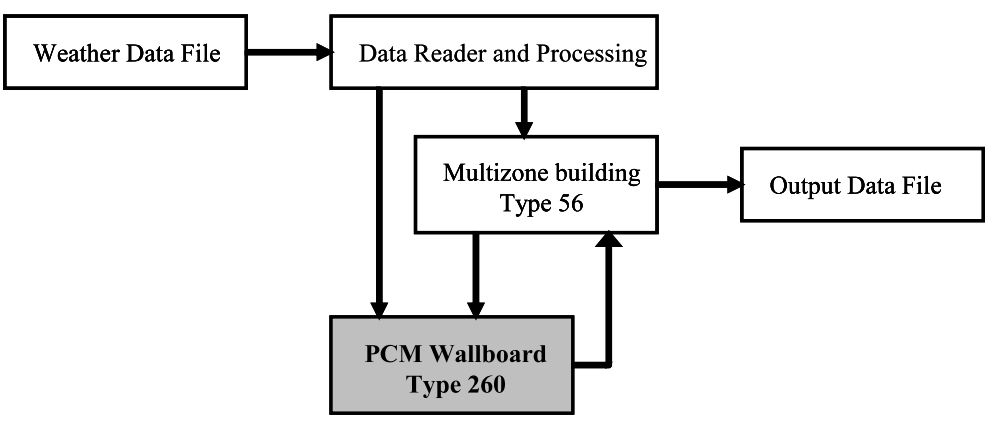

Figure 3: TRNSYS flow diagram with PCM type. 


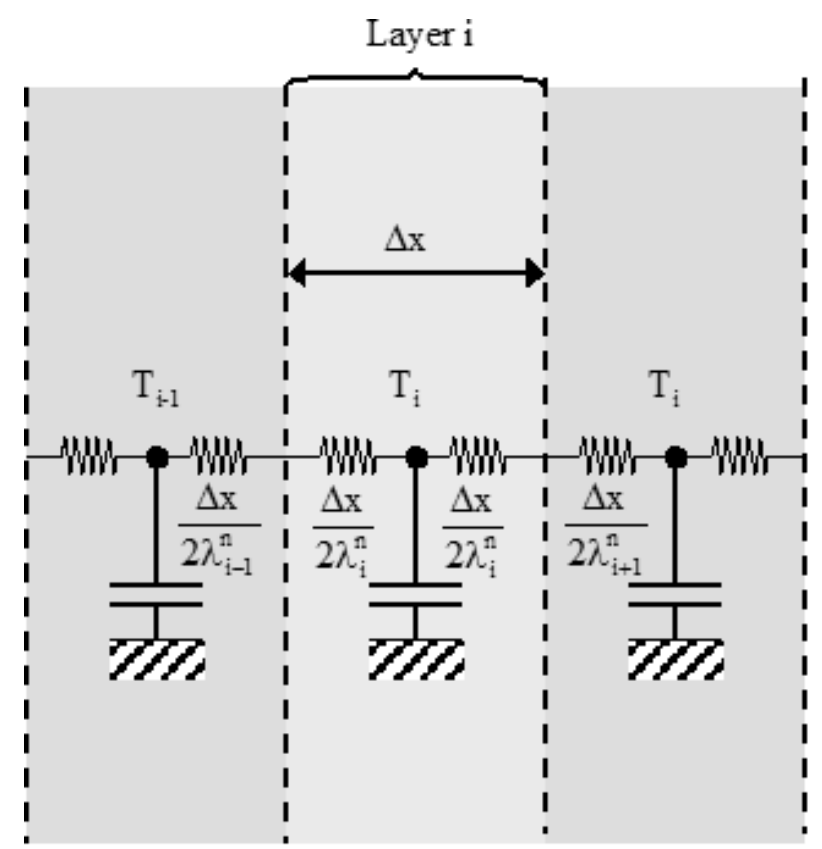

Figure 4: RC model of the wallboard. 


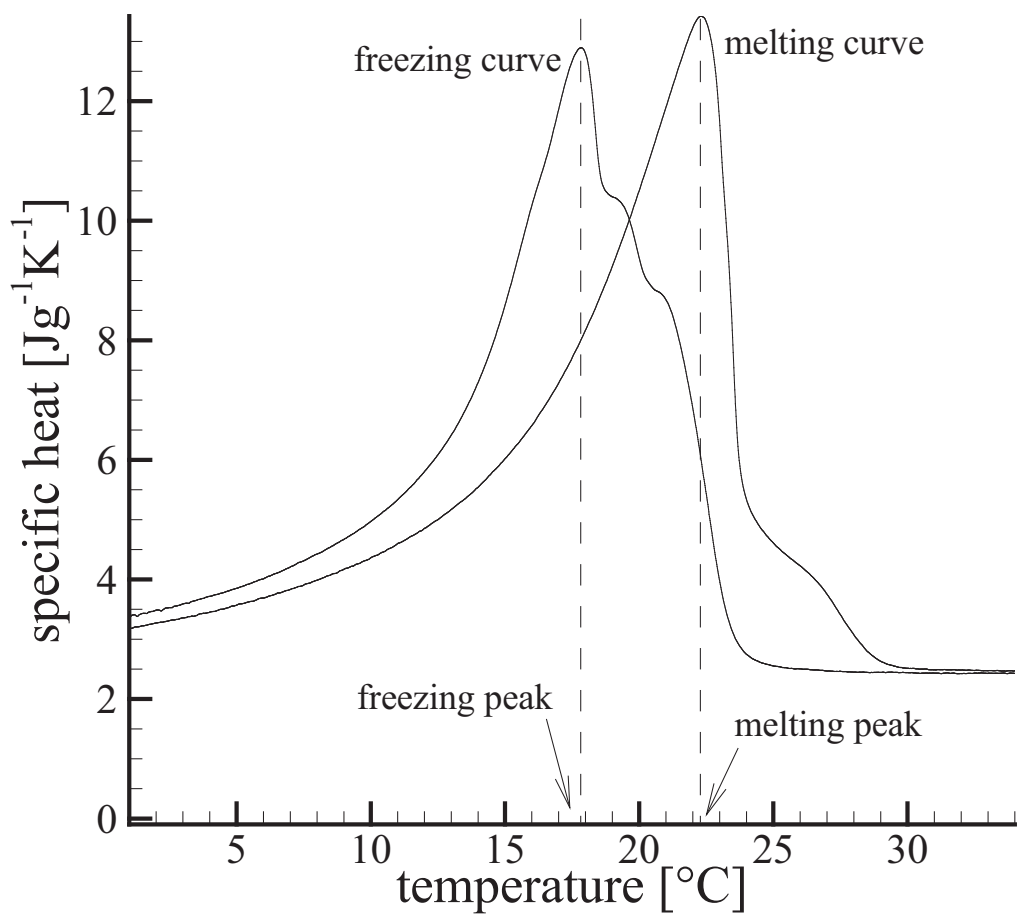

Figure 5: Measurement of the PCM heat capacity. 


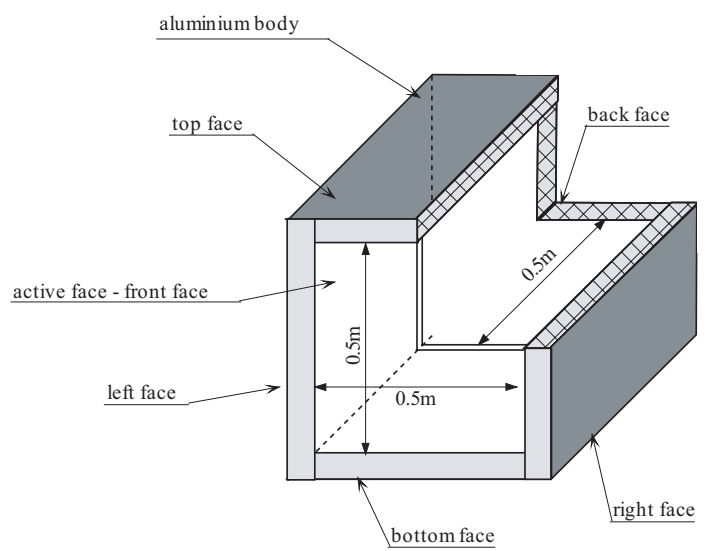

Figure 6: Schematic view of the experimental cell MICROBAT. 


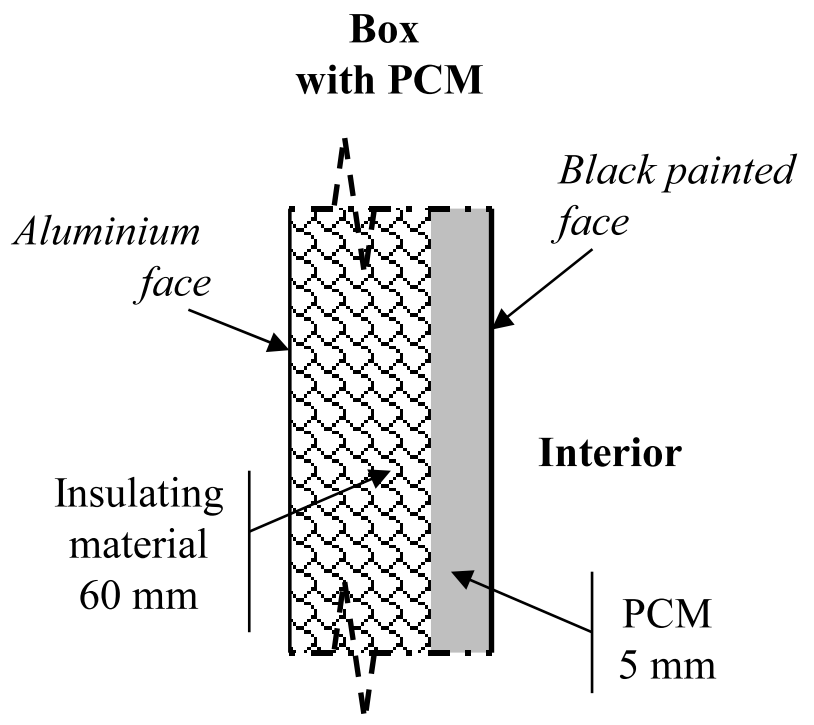

Figure 7: Wall composition of the box with PCM. 


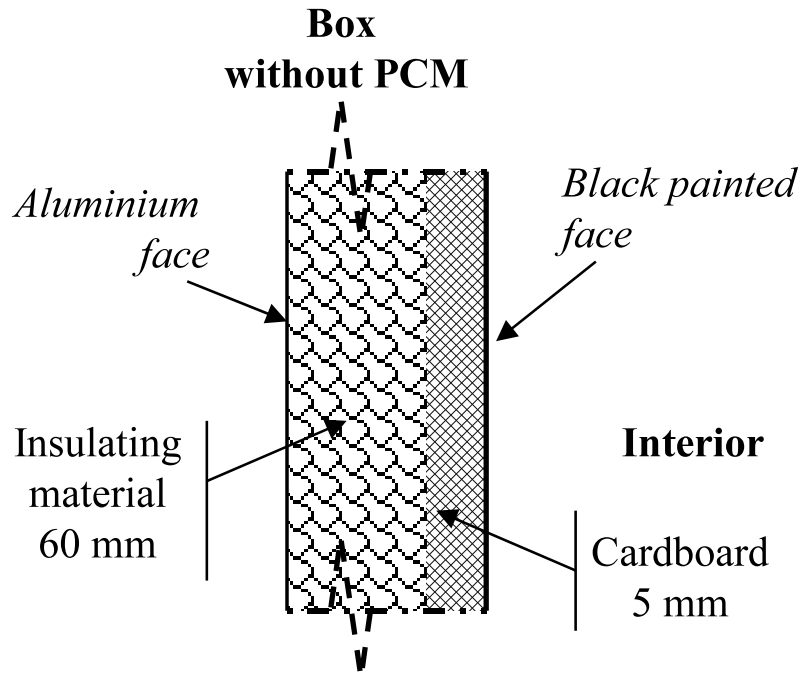

Figure 8: Wall composition of the box without PCM. 


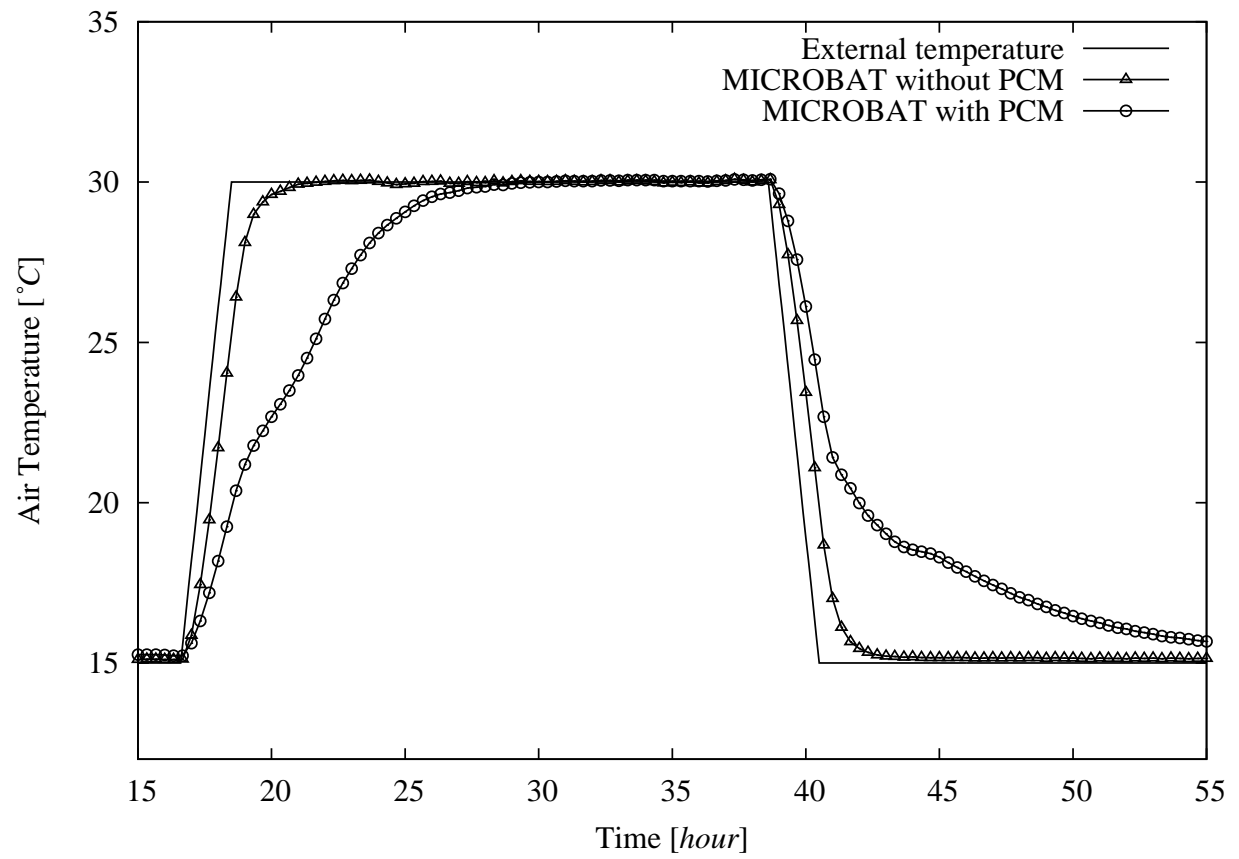

Figure 9: Experimental cells air temperatures with and without PCM: two hours increase/decrease. 


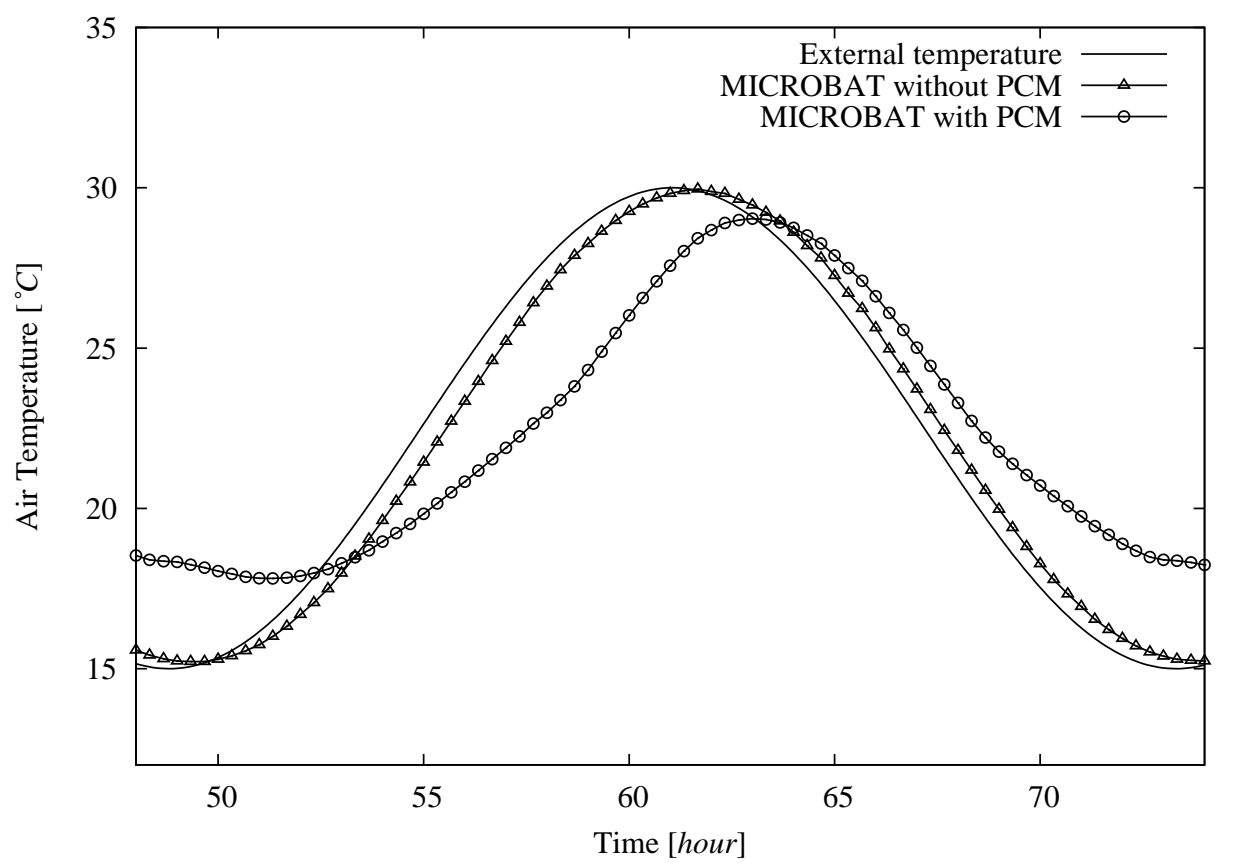

Figure 10: Experimental cells air temperatures with and without PCM: Sinusoidal temperature. 


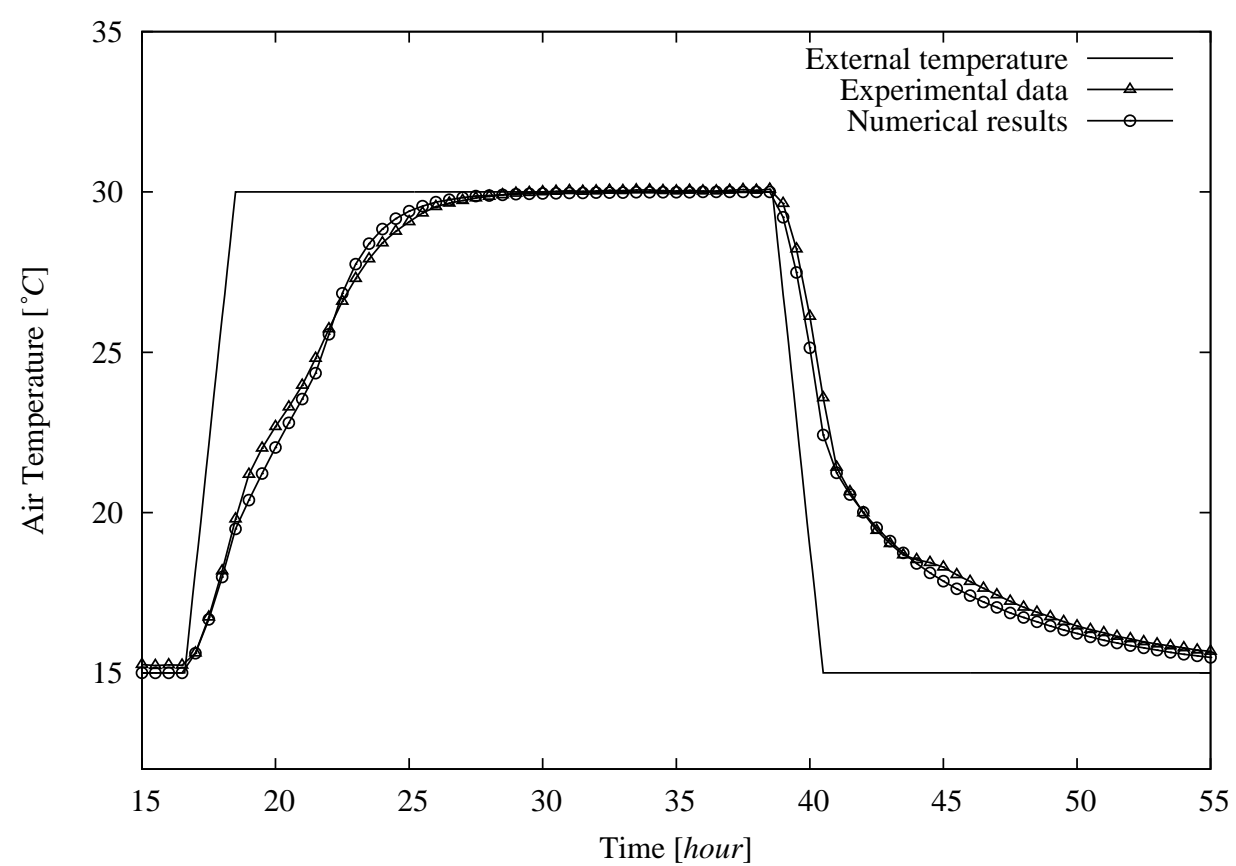

Figure 11: Comparison of simulated and measured air temperature of the test cell with PCM: two hours increase/decrease external temperature. 


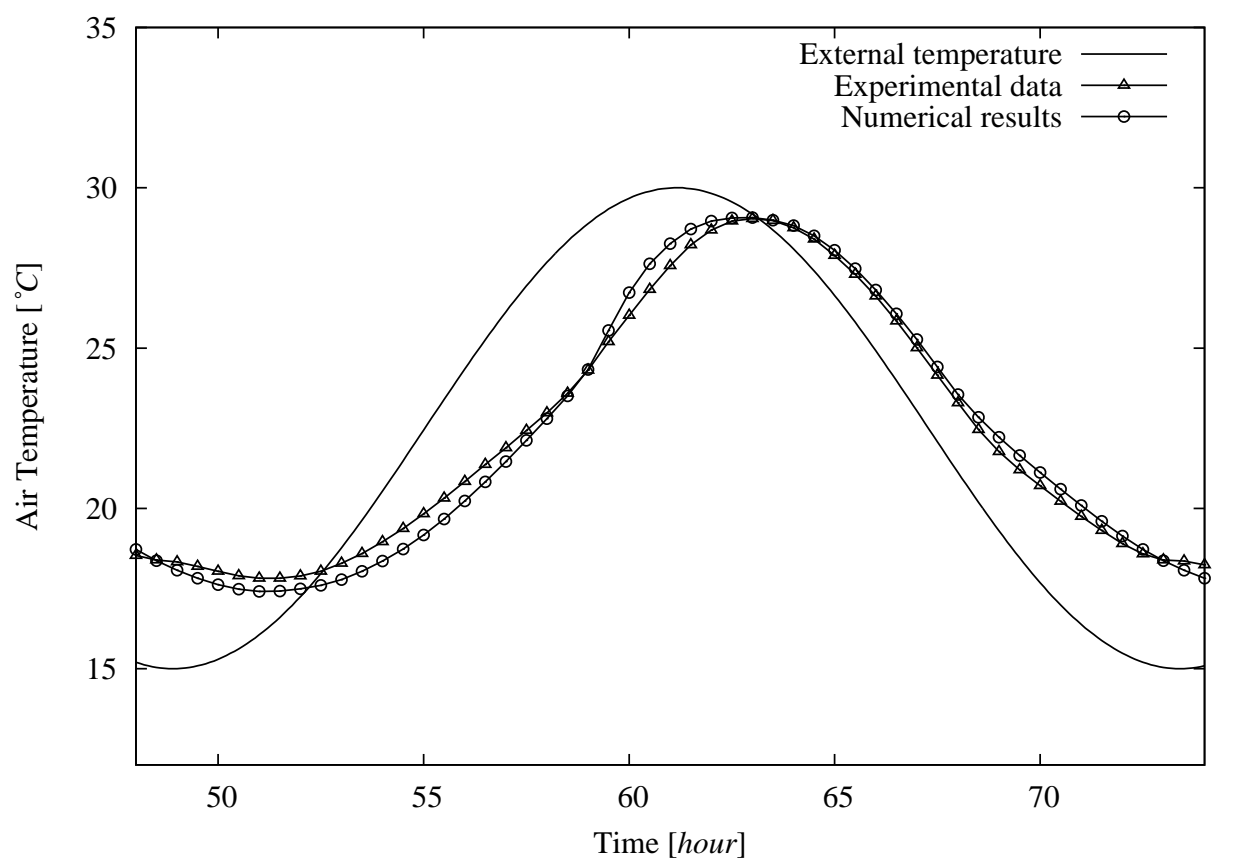

Figure 12: Comparison of simulated and measured air temperature of the test cell with PCM: sinusoidal external temperature. 


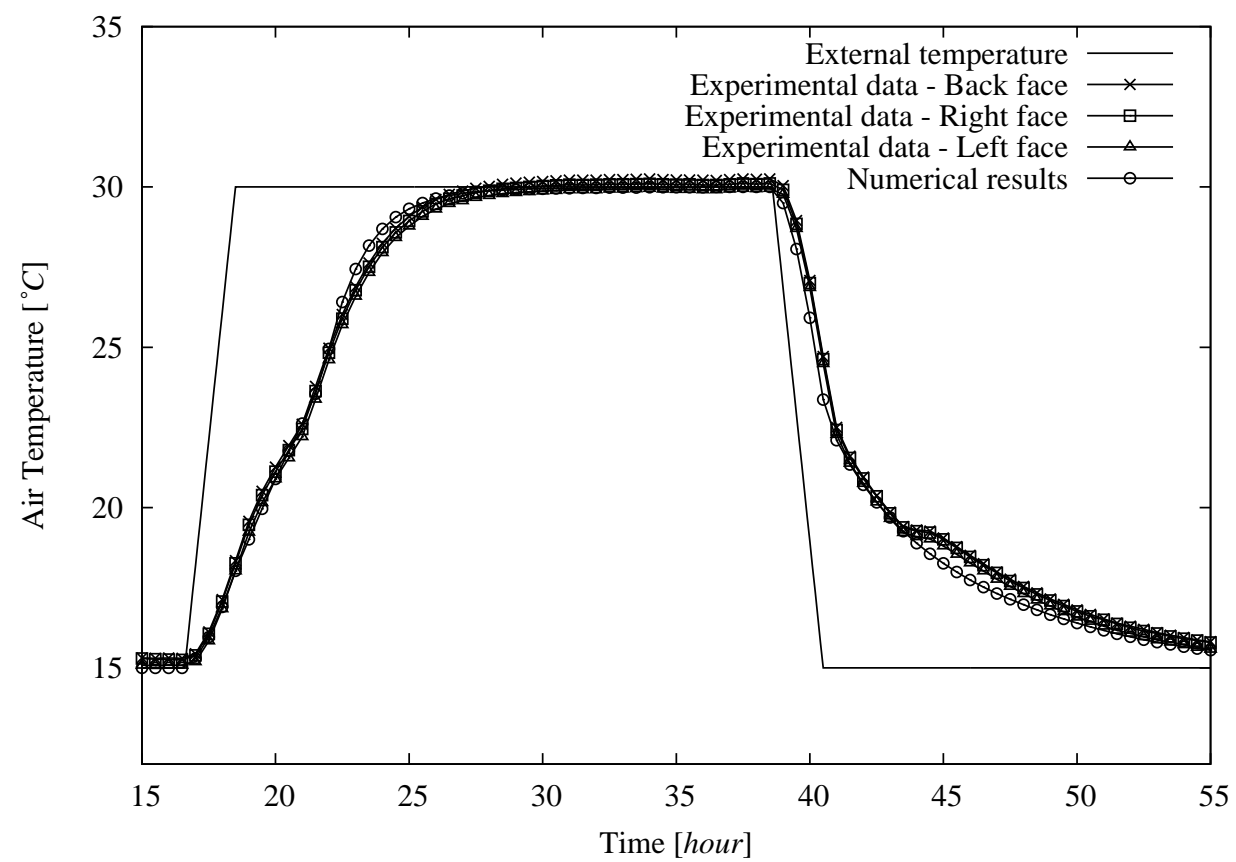

Figure 13: Comparison of simulated and measured inside vertical surface temperatures of the test cell with PCM: two hours increase/decrease external temperature. 


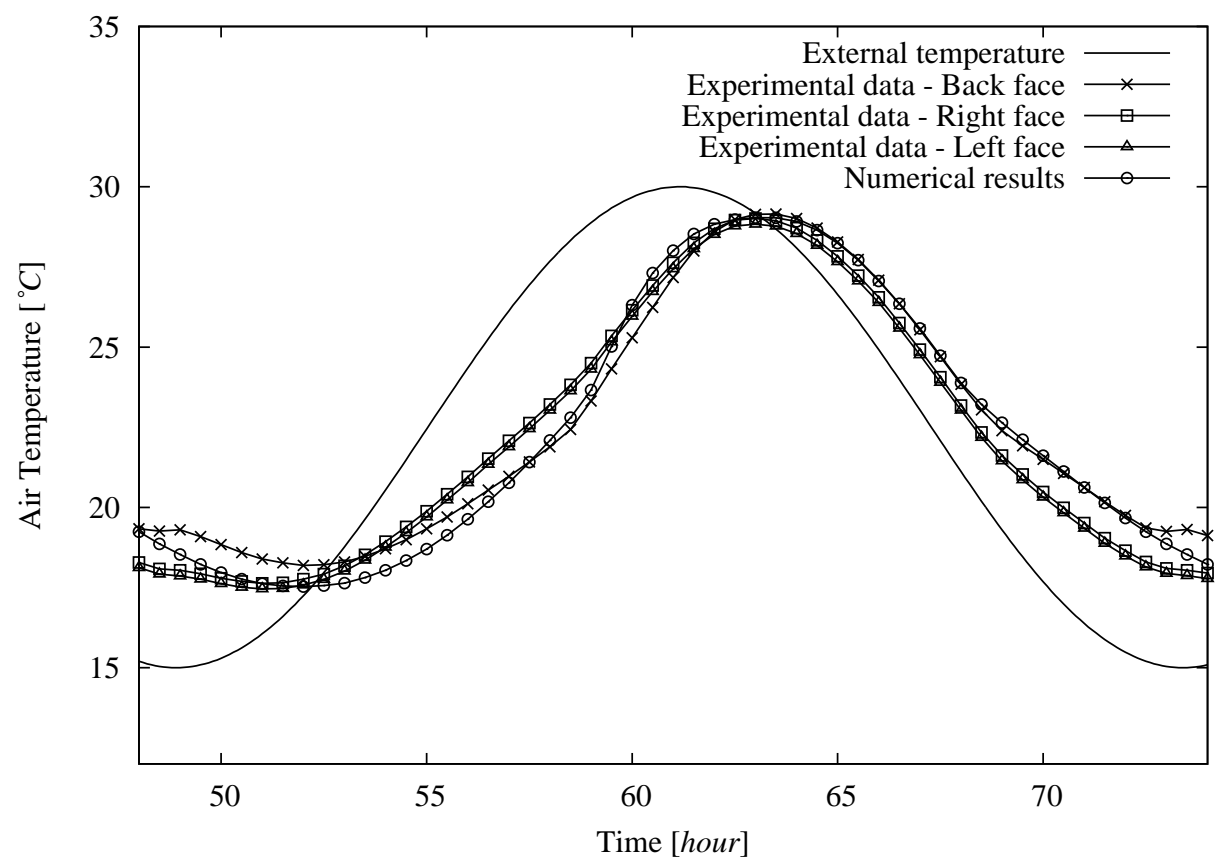

Figure 14: Comparison of simulated and measured inside vertical surface temperatures of the test cell with PCM: sinusoidal external temperature evolution. 